\title{
More than Twenty Years of Svensén's Handbook
}

Loránd-Levente Pálfi, Centre for Lexicography, Aarhus School of Business, University of Aarhus, Denmark (llp@asb.dk)

\begin{abstract}
The number of real handbooks dealing with lexicography and metalexicography is not, and has never been, impressive. When one looks at comprehensive handbooks and in addition those brought up to date, the number becomes even smaller. Because of this, but also because it has existed for more than 20 years (i.e. in different editions/versions) and because it is - especially in Scandinavia - a quite well-known work, Svensén's handbook is an important publication. In this review article, I will consider what the critics have written over the years (i.e. on the different editions/versions of Svensén's handbook), and I will attempt to determine whether the book is about to become a classic.
\end{abstract}

Keywords: LEXICOGRAPHY, METALEXICOGRAPHY, HANDBOOKS, SCHOLARLY REVIEWING, CITATIONS, A HANDBOOK OF LEXICOGRAPHY, BO SVENSÉN, THE ART AND CRAFT OF LEXICOGRAPHY, SIDNEY I. LANDAU, MANUAL OF LEXICOGRAPHY, LADISLAV ZGUSTA

Opsomming: Meer as twintig jaar van Svensén se handboek. Die aantal werklike handboeke wat die leksikografie en die metaleksikografie behandel, is nie en was nog nooit indrukwekkend nie. Wanneer 'n mens na omvattende handboeke kyk en daarby dié wat bygewerk is, word die aantal selfs kleiner. Om dié rede, maar ook omdat dit vir meer as 20 jaar bestaan (d.w.s. in verskillende uitgawes/bewerkings) en omdat dit — veral in Skandinawië — 'n redelik welbekende werk is, is Svensén se handboek ' $n$ belangrike publikasie. In hierdie resensieartikel sal ek oorweeg wat die kritici oor die jare geskryf het (d.w.s. oor die verskillende uitgawes/bewerkings van Svensén se handboek), en sal ek probeer bepaal of die boek besig is om 'n klassieke werk te word.

Sleutelwoorde: LEKSIKOGRAFIE, METALEKSIKOGRAFIE, HANDBOEKE, VAKKUNDIGE RESENSERING, AANHALINGS, A HANDBOOK OF LEXICOGRAPHY, BO SVENSÉN, THE ART AND CRAFT OF LEXICOGRAPHY, SIDNEY I. LANDAU, MANUAL OF LEXICOGRAPHY, LADISLAV ZGUSTA

The book discussed in this article is Bo Svensén's A Handbook of Lexicography. The Theory and Practice of Dictionary-Making (2009). A previous English version was published under the title Practical Lexicography. Principles and Methods of Dictionary-Making (i.e. Svensén 1993). Originally the book appeared in Swedish in 1987. A revised and extended edition of the Swedish version was published under the title Handbok i lexikografi. Ordböcker och ordboksarbete $i$ teori och praktik (i.e. Svensén 2004). 
Whereas, on the one hand, the difference between Practical Lexicography [...] (1993) and Handbok $i$ lexikografi [...] (2004), as Varantola (2006: 107) also partly argues, and, on the other hand, the difference between Practical Lexicography [...] (1993) and A Handbook of Lexicography [...] (2009), as Trap-Jensen (2010: 223) argues, is big enough for the latter two, i.e. the titles from 2004 and 2009 , to be regarded as new versions rather than new editions compared with the titles from 1993 and 1987, the difference between Handbok i lexikografi [...] (2004) and A Handbook of Lexicography [...] (2009) is quite small - apart from the fact that the one is written in Swedish while the other is a somewhat revised edition written in English; cf. however Trap-Jensen (2010: 226):

The English edition [i.e. Svensén 2009] is much more than a translation of the Swedish original [i.e. Svensén 2004]. Many content revisions have been made to cover the developments that have taken place in the five-year period between the two editions. The most obvious difference, however, is the large number of examples that have been replaced to cater for the change in readership from Scandinavian users to the English-speaking international world. The Swedish examples used for monolingual dictionaries have largely been replaced by English ones, and bilingual examples are usually between English as L1 and French or German as L2. Similarly, the bibliographical references have been adapted to an international audience, dominated by English texts with a supplement of German and French texts and only a few selected texts in a Scandinavian language.

Whether new versions or new editions, Svensén's handbook has been on the market for more than 20 years. And all the editions/versions have been produced by Svensén himself (except the version from 1993, which is a translation by two professional translators). This is a remarkable achievement by one man in the modern history of metalexicography. It seems to be time to make a status report on the life of this handbook. In the following, I will take a look at what previous reviewers have commented on the work (the versions of 1993 and 2004), and I will try to establish whether or not the critique has resulted in changes in the English edition from 2009. I will also look at critique of the 2009 edition, adding my own comments. There is only one review of Svensén's handbook that is not treated with here: A very short review written by Ladislav Zgusta and published in the DSNA journal Dictionaries 14, dealing with the first Swedish version from 1987, and, because it forms part of a discussion of several other books, containing little communication on the book.

McCreary (1997) is the first reviewer to be dealt with here. He reviews Svensén (1993) and thereby raises the following "minor irritations" (McCreary 1997: 346): In his opinion the book (a) has a Eurocentric perspective, (b) is written in a dry prose, and (c) has an inadequate index. Besides these problems, McCreary (1997: 347) is quite positive on the book.

Regarding point (a), he says:

As a lexicographer with experience in Japanese-English dictionaries, I was disappointed with the book's exclusively Eurocentric perspective. However, the 
chapters above on the construction of definitions and the choice of bilingual equivalents could be helpful to the lexicographer in Asia (or anywhere for that matter) who wants to examine the various methods of definition construction and the various orderings of senses for polysemous words.

I do not agree with McCreary on this issue. One can take a look on this matter from an opposite angle, as Varantola (2006: 108) does:

A clear advantage of the Handbok is that Svensén is extremely well-read in multilingual lexicographical literature and is thus able to describe lexicographical practices in different countries. In addition to English, he also draws examples from a number of other languages, such as Swedish, German and French. In this way he is able to highlight problems that do not necessarily come up in English dictionaries.

Regarding McCreary's (1997: 347-348) point (b), the following two quotations can serve as clarification:

In a number of chapters, the reader has a feeling that the English has been closely and accurately translated, but is lacking in idiomatic natural English, which unfortunately lends a dry tone to the work. Some suitably colorful English idioms along with a livelier writing style would have been appreciated. [...] Considering that it is an exhaustive treatment of all of the elements in dictionaries and systematically presents all of their functions for both native and non-native users, the text is very readable, although not as readable as Landau's (1984) work. [...] Svensén's book is similar to Zgusta's (1971) text. Similarly, this quality of systematic thoroughness can make it a suitable text for a graduate course in lexicography. However, those who choose it for a graduate course might want to supplement it with another more general book with a more readable style, such as Landau's (1984) book.

In this regard, I must agree with McCreary - and I can add that this has not changed for the better in the 2009 edition. On the contrary. The 1993 version was translated by two professional translators; the 2009 edition has been translated by Svensén himself. This is my opinion; others may disagree, as for instance Trap-Jensen (2010: 226):

Combined with the fact that the English translation from Swedish is, to my judgment, accurate and idiomatic, conscientiously rendering the author's precise and sober-minded style of writing, there is no reason, neither with respect to focus nor to language, why the book should not find the large and responsive audience it deserves.

Regarding McCreary's point (c), the following quotation can serve as clarification: "The text concludes with a useful but occasionally cursory subject index (pp. 281-285), which should have been supplemented by an author index" (McCreary 1997: 347). In this case, there have been some improvements: The index 
in the 2009 edition is much more adequate than the one in the 1993 version, but an author index is still lacking. And even if the index in the 2009 edition is better than that found in many other books, it still has some shortcomings; cf. for instance the entry "L2 $\rightarrow \mathrm{L} 1$ dictionaries":

\section{$\mathrm{L} 2 \rightarrow \mathrm{L} 1$ dictionaries (see also bilingual dictionaries) 14-18, 37, 61-2, 66, 68, 70, 73, 88, 115, 125, 126, $128,129,131,144,155-7,175-7,181,193,198$, 202-3, 260, 263, 267, 269-71, 275-6, 278-9, 293, $299,313,324,349,353-7,376,393,395-6,446$, $464-5,466,467-9$}

In the field of LIS (i.e. library and information science), this is called a burial an LSP word denoting that so many references are given that the information, which one wishes to make accessible, in fact literally becomes buried, and therefore inaccessible. However, in many other connections Svensén is obviously aware of the concept of burials, since he often makes the necessary specifications by using sub-entries (which, by the way, is the common solution for this problem); cf. for instance the entry "lexicography":

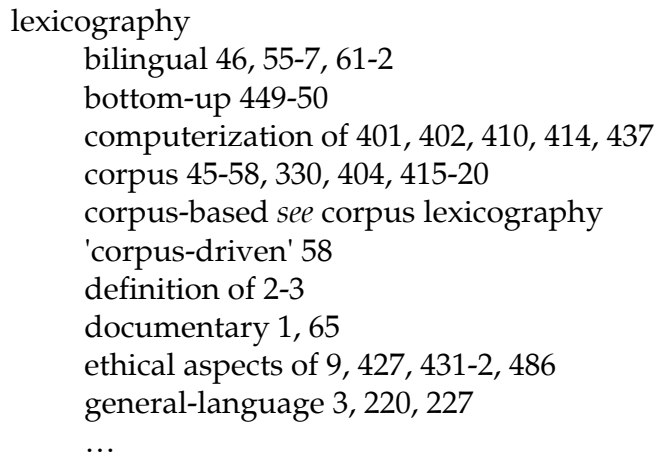

The index certainly deserves to be praised. At the same time, there are still quite a number of burials that should have been avoided. And it is regrettable that the reader still cannot look up names.

The next two international critics in line are Varantola (2006), who reviews Svensén (2004), and Trap-Jensen (2010), who reviews Svensén (2009). The former (Varantola 2006: 107) is of the opinion, that Svensén should have given much more space to electronic lexicography:

Only in one chapter is the electronic medium in all its dimensions treated separately, namely in the section dealing with electronic dictionaries. [...] the electronic medium has affected so many lexicographical axioms and principles of dictionary compilation including entry presentations that they alone would merit a new standard handbook in the field. 
This has not changed in the 2009 edition. Cf. Trap-Jensen (2010: 226), who obviously agrees with Varantola (2006) and repeats the critique in somewhat other words:

Even though the author has no doubt invested considerable effort to incorporate many new aspects pertaining to e-dictionaries throughout the book, the book cannot avoid a bias towards the printed medium. The next generation of lexicographic textbooks will, at least in this reviewer's opinion, have to reflect the twosided nature of modern dictionary-making: on the one hand, it must deal with the compilation, organization and storage of dictionary data in a database independently of the channel of publication and, on the other hand, it must discuss how those data are presented to the user, whether in a printed book or on a screen. That would lead to the inclusion of chapters on database architecture, data markup and schemas and it would lead to other chapters dealing with topics such as web design and user customization for e-dictionaries, and space-saving strategies such as the use of abbreviations and symbols for print dictionaries. And in return, chapters on micro-, macro- and cross-reference structure are more or less irrelevant for e-dictionaries and would have to be rewritten to be compatible with the dual model of data organization and data presentation.

One should keep in mind, however, that the world is not spinning around the web. The number of printed media is bigger today than it has ever been before. Billions of documents, actually, are being produced in the world each day (cf. Pálfi 2010b). The web is not included in this number. Surely a new handbook (or several handbooks) with the main focus on electronic lexicography and the digital world must - and will probably soon - appear. Svensén's handbook with its main focus on the printed media will still be necessary.

The next critical point from Varantola (2006: 107) regards the targeted readership and the overall style (macro- and megastructure) of the book:

The scope of the manual is broad and therefore problematic, because it is clear that these target groups [i.e. lexicographers, language students and teachers, language planners, and translators] have different needs and interests. It is difficult to imagine that the book could as such be used as a textbook for language students as it is too detailed in its lexicographical classifications. On the other hand, the book could be gainfully used as a reference work and additional reading material for lexicographical projects in language studies.

Trap-Jensen (2010: 224) has a somewhat opposite view on this topic (it should be noted that Trap-Jensen's review regards the 2009 edition, whereas Varantola's review regards the 2004 version):

A connected question is whether the book is primarily an introduction to lexicography as an academic discipline or a reference book for practitioners in the field. The book itself does not provide the answer. [...] The structure of the book is such that each chapter addresses one component of the dictionary entry and analyses it in relation to the various types of dictionaries. This is the result of a choice made by the author and it has the advantage that all the components can 
be described exhaustively in their own chapters and by the use of comparative analysis. In my judgment, this structure is more expedient in a textbook for metalexicographers and students of lexicography but less attractive when used in a handbook for dictionary practitioners. The latter are not likely to be interested in comparative analyses of how the same dictionary element is treated in different dictionaries. More likely, they want to learn what kind of data they should include in their dictionary and how to present it in the concrete project at hand. Imagine a lexicographer writing a bilingual L2-L1 dictionary: she would have to read through the whole chapter on the relevant element, carefully picking out those passages that are relevant for her L2-L1 dictionary. This makes it more difficult for her to use the book as a handbook for quick reference in everyday situations. The impatient reader who wants a quick overview of a specific problem will have to try his luck via the initial table of contents or the 15 pages subject index at the end of the book.

I do not agree with either of the two. Svensén's book is a typical, classical handbook in the European tradition which goes back for centuries. This kind of book provides in-depth information - the incomparable Hausmann et al. (1989-1991) also is such a kind of handbook — and is not meant to be used for quick reference like a dictionary. If in-depth information on the core aspects of lexicography cannot be obtained from a handbook like this, where then should one look? Should one read several monographs (instead of reading chapters comprising about 10-30 pages in Svensén's handbook) every time one wants to gain insight into a specific aspect of lexicography or metalexicography, i.e. an insight much more comprehensive than that gained by a regular dictionary look-up (for instance in a dictionary like Martínez de Sousa 1995, Burkhanov 1998 or Hartmann and James 2006)? The targeted readership of handbooks of this type is broad, so this is characteristic of this kind of publication. I find it problematic to present - as an example of a potential user - a superficial, impatient dictionary-compiler (cf. the quote from Trap-Jensen above). Compiling a dictionary is not a task with which one is occupied for a week or two. One must do thorough and serious research, which includes not only reading Svensén's handbook or consulting some chapters in it, but also reading many other sources.

Varantola (2006: 108) is complimentary on the bibliography: "The book [...] has a very extensive bibliography, a treasure for anyone embarking on a study of any aspect of lexicography, as well as a detailed index." Trap-Jensen (2010: 225) seems to agree, as he mentions "the voluminous 32 pages bibliography at the end of the book". Svensén's bibliography is not thin, but it does not impress either if compared with bibliographies in other publications. Cf. for example Considine (2008), which is a monograph consisting of 322 pages (bibliography and index excluded) and containing a bibliography comprising 52 pages. (See also Pálfi 2009b: 511.) Considine's bibliography is indeed impressive considering that it is a monograph, and not a handbook. Another example: The bibliography in Pálfi (2010a) comprises 172 pages (the whole book consisting of 432 pages). It is a dictionary of dictionaries similar to Kabdebo and 
Armstrong (1997), the difference being that the dictionary of Kabdebo and Armstrong concerns English dictionaries (i.e. dictionaries from the UK, the USA, Australia, Ireland etc., with English as either language of communication or as one of the languages treated within the dictionaries in question), while Pálfi (2010a) concerns Danish dictionaries. A praiseworthy bibliographic feature in Svensén's handbook (the 2004 version and the 2009 edition), however, is, according to Trap-Jensen (2010: 225-226), the following:

As a new feature, the book has at the end of each chapter a section with suggested further reading, not just in the form of a list of titles and authors but an annotated list with specifications on the subject, on model examples or on theoretical discussions of a particular aspect. [...] The value of this feature can hardly be exaggerated and will undoubtedly save a lot of time and effort for lexicographers and students on the lookout for relevant literature.

Another praiseworthy feature of the book, on which also Varantola (2006: 108) comments regarding the 2004 version, and which has been left unchanged in the 2009 edition, is the following:

Svensén is a very non-committal writer. He does not normally advocate one approach or solution over another but describes different solutions and principles impartially. Only towards the end of the book, where he tackles ethical and legal issues, such as plagiarism, copyright, and marketing ethics, does he take firmer standpoints. In other words, Svensén has obviously wanted to write a manual that provides multi-faceted information about the various dimensions of dictionaries and dictionary-planning for the benefit of lexicographers and editors who need the information for their own decisions.

The reverse side of this, however, is the dry prose/tone, which is probably also connected with the non-committal writing style (however, the Swedish version of 2004 does not suffer from this dry prose/tone). All in all, both Varantola (2006) and Trap-Jensen (2010) are very positive about Svensén's handbook. At the same time, the latter raises a criticism, with which I agree:

A single point of criticism stands out, however: the book is bound to be more or less out of date from the very day of its appearance. This is of course often the case with publications in a rapidly changing field and cannot be helped. Unfortunately, the situation is in this case aggravated by the time spent on translation and the adaptations needed for international publication: Svensén began working on the Swedish edition some years before it appeared in 2004 and it took another 5 years before the current English edition came out.

Admittedly this is a choice not easily made: Either one can share the work with one or several other scholars (thereby speeding up the time of production of the given book) and possibly also safeguard oneself against errors of detail, that otherwise might pass unnoticed (cf. Pálfi 2009c: 518), or one can choose to be the sole author. Also co-authorship has its negative consequences: the risk of lack of terminological consistency, of cohesion between the individual chap- 
ters, of common basic assumptions and starting-points, of common theoretical groundwork etc. (cf. Pálfi 2009c: 518-519).

The longest and most thorough review of Svensén's handbook comes from Vikør (2005), who deals with Svensén (2004). Vikør's review which comprises 16 pages is written in Norwegian. Being initially and conclusively very positive, Vikør partly raises a number of errors of detail in his critique, and partly he is trying to summarize the contents of the book. Only some of the most significant errors of detail observed by Vikør shall be mentioned in the following. For instance, Vikør (2005: 338) points out that Svensén (2004: 28) erroneously regards synonym dictionaries as onomasiological dictionaries, which, Vikør argues, is a misunderstanding (although one which not only Svensén is guilty of, but also numerous other scholars in the field of lexicography and metalexicography), since synonym dictionaries have an alphabetical macrostructure opposed to thesauruses, that have an onomasiological macrostructure, i.e. according to meaning. This has been corrected in the 2009 edition, cf. for instance Svensén (2009: 30-31). Vikør (2005: 336-337) furthermore considers Svensén's (2004: 29-30) treatment of the dictionary and the norm (i.e. normative vs. descriptive dictionaries etc.) inadequate. This also seems to have been changed in the 2009 edition (cf. for instance Svensén 2009: 24). Vikør (2005: 334-335) finds it somewhat problematic that the Swedish version of 2004 focuses too strongly on Swedish lexicography: The book would have been more Nordic in essence and concept had it also contained more examples from Norwegian and Danish dictionaries, i.e. more references to Norwegian and Danish lexicography (not to speak of Finnish, Icelandic, Faroese, and Greenlandic lexicography). However, this detail does not relate to the English edition of 2009, which is solely conceived for an international audience, and in which most of the examples have been replaced by mostly English material.

The only entirely negative reviewer in the existence of Svensén's handbook is Tarp (2005). His review is written in Danish. Although Tarp also makes some positive remarks, he is initially, medially and conclusively negative. For instance, Tarp (2005: 6) highlights some introductory passages from Svensén (2004), which in content have not changed in the 2009 edition: "There are those who argue that lexicography is a kind of applied linguistics, while others (among them the author of this book) regard it as in independent discipline" (Svensén 2009: 3). The problem here, Tarp argues, is that this formal position of Svensén does not affect the rest of the book. Tarp subscribes to this position that lexicography/metalexicography is a separate scholarly discipline and not a part of linguistics (cf. for instance Tarp 2008 et passim). Svensén obviously agrees, but, according to Tarp, does not take the consequences of this position further than page 3 (in the Swedish version of 2004 page 4). Another example highlighted by Tarp is the following (Svensén 2009: 2):

Lexicography is an activity which consists in observing, collecting, selecting, analyzing and describing, in a dictionary, a number of lexical items (words, word elements and word combinations) belonging to one or more languages. 
In the Swedish version of 2004, this paragraph appears on page 3. Tarp (2005: 6) argues: That which makes lexicography a separate scholarly discipline in relation to linguistics is the fact that it has dictionaries and not language as its theoretical focus, and that its practical focus is the making of dictionaries for a given user group in accordance with optimizing the genuine function of the dictionary as a tool for information retrieval. Hence it is not "lexical items" that is the pivotal point, but those specific problems that specific user-groups may encounter in specific user situations. In addition, Tarp (2005: 7) argues that Svensén's handbook cannot and should not be used to learn something about lexicographic theory. The dictionary typology proposed in Svensén (2004) Tarp also finds quite problematic, since it relies more on traditional linguistic scholarship than on modern metalexicography. However, the pages on dictionary typology have been rewritten in the English edition of 2009. It therefore seems Svensén has accepted some of the criticism raised by Tarp. Another problem of concern, Tarp argues, is the chapter 'Ordboksprojekt' (in the English edition of 2009 it is called 'Dictionary projects'). Here, among others, Svensén distinguishes between "project plan" and "dictionary plan" and gives the reader the impression that the former is mainly conceived by administrators, marketers, economists and legal consultants, while the latter is conceived by the lexicographer(s) only (this goes for the Swedish version of 2004 as well as the English edition of 2009; for the latter, see for instance pages 399-402 and 405-406). Tarp finds this more than problematic, since the "project plan" in Svensén's chapter includes such very central issues as dictionary functions: It is mainly the lexicographer, Tarp argues, who should occupy him-/herself with such issues as dictionary functions, user groups and user needs, not administrators, marketers, economists or legal consultants. I agree with this specific aspect. As becomes clear from above, these paragraphs do not seem to have been changed or corrected in the 2009 edition. All in all, Tarp argues that the book should be used by specialists, i.e. lexicographers and metalexicographers only, because these will be likely to see the gaps and inadequacies. Students and semi-experts (among these specialists from neighbouring disciplines) should not use the book, i.e. in the view of Tarp. To accommodate Tarp's critique completely would have meant rewriting extensive parts of the book - which Svensén has not done with the 2009 edition. Even though, for a greater part, I agree with Tarp, I find the issue not as problematic as he does. For some reason or another, Svensén still seems to have managed to write a truly metalexicographic book opposed to, for instance, Considine (2008), which is a book from and for the field of LIS (i.e. library and information science) rather than from and for the field of lexicography and metalexicography. What I concluded about Considine (2008) (cf. Pálfi 2009b: 514), certainly does not apply to Svensén's handbook:

The most significant and recurring deficiency of the book is the general lack of metalexicographic reflection. [...] Dictionaries in Early Modern Europe is evidently written by a philologist with a profound interest in historical bibliography for other philologists with the same interest. [...] The book will certainly be of great 
value and use primarily for philologists, librarians, book historians, historical bibliographers, and secondarily for historians and cultural historians. Dictionary historians, in so far as these regard themselves metalexicographers, and metalexicographers in general, will find the book lacking in metalexicographic reflection. [Pálfi 2009b: 512] All in all, Dictionaries in Early Modern Europe is an exceptionally erudite, thorough and trustworthy book [...], however, the book is of little value for metalexicographers.

Svensén's handbook is about to become a classic - in the sense of 'a publication that is being re-edited and reprinted again and again, and is known and used around the world'. Or is it? In the following, I will look at some citation figures. The figures for IJL were harvested with the help of the search engine on the IJL website (however, one has to be aware of the fact that the total number given for a search does not equal the right information: one has to check every search result for every publication found by the search engine to exclude reviews of the given books, self-citations, double showings, etc.). The figures for LexicoNordica have been harvested manually, since LexicoNordica, although it has a homepage and an online as well as a printed version, does not have a search engine like IJL.

One can only wonder why Svensén's handbook (1987/1993/2004) is cited surprisingly little in comparison with Zgusta's Manual of Lexicography (1971), which, one would think, is rather outdated. Thus Svensén's handbook (1987/ 1993/2004) has until now (i.e. June 2010) only been cited 12 times in International Journal of Lexicography, the first time being in 1998. The three citations by the reviewers McCreary (1997), Varantola (2006), and Trap-Jensen (2010) are not included in this figure. From these 12 scholars ${ }^{1}$ only one is from the USA, while the 11 others are from Europe (8), China (1), Japan (1), and Australia (1). From these 12 citations, 10 refer to Practical Lexicography [...] (1993), and two to Handbok i lexikografi (2004). Zgusta's Manual of Lexicography (1971) is cited 29 times (in this figure the two occurring self-citations from Zgusta himself are not included). The citations are by scholars from Europe (13), the USA (7), Japan (3), Russia (1), China (1) and Australia (1), while three citations are of mixed origin. ${ }^{2}$ If one looks at Sidney Landau's Dictionaries: The Art and Craft of Lexicography (1984/1989/2001), the following figures appear: Europe (16), ${ }^{3}$ the USA (5), Japan (3), ${ }^{4}$ Canada (2), ${ }^{5}$ China (2), New Zealand (2), Kuwait (1), Jordan (1), ${ }^{6}$ Australia (1), ${ }^{7}$ while two citations are of mixed origin. ${ }^{8}$ The figures for Landau are 35 in total. The two reviews of Landau's book in IJL and the two occurring self-citations by Landau himself are not included in these figures. That IJL was launched in 1988 compensates for the fact that Landau's book first appeared in 1984, whereas the first English version of Svensén's book was published in 1993. The figures for the three are as follows (citations are included from any kind of contribution, i.e. articles, review articles and reviews of other books than Zgusta 1971, Landau 1984/1989/2001, and Svensén 1987/1993/2004 investigated here): 


\begin{tabular}{|l|c|}
\hline Landau, Zgusta, and Svensén & Citations in IJL 1988-June 2010 \\
\hline Dictionaries [...] (1984/1989/2001) & 35 \\
\hline Manual of Lexicography (1971) & 29 \\
\hline Svensén's handbook (1987/1993/2004) & 12 \\
\hline
\end{tabular}

If one considers the citation figures for Zgusta (1971), Landau (1984/1989/ 2001), and Svensén $(1987 / 1993 / 2004)$ in the journal LexicoNordica (which is a scholarly, peer-reviewed journal of about 250-350 pages, appearing annually in November since 1994 as a publication of the Nordisk Forening for Leksikografi, cf. Pálfi 2009a), the following results can be presented (as above, with the same exceptions, citations being included from any kind of contribution):

\begin{tabular}{|l|c|}
\hline Svensén, Landau, and Zgusta & Citations in LexicoNordica 1994-2009 \\
\hline Svensén's handbook (1987/1993/2004) & 43 \\
\hline Dictionaries [...] (1984/1989/2001) & 5 \\
\hline Manual of Lexicography (1971) & 5 \\
\hline
\end{tabular}

Svensén $(1987 / 1993 / 2004)$ is cited 43 times in total: Swedish (24), ${ }^{9}$ Danish (10), ${ }^{10}$ and Norwegian (9)..$^{11}$ In these figures Vikør (2005), which is the only review of Svensén's handbook in LexicoNordica, is not included, nor are six selfcitations by Svensén. For Landau, the specifications are as follows: Swedish (4),,$^{12}$ and Danish (1). The only review of Landau (2001) in LexicoNordica is not included in these figures. For Zgusta, the specifications are as follows: Swedish (3), ${ }^{13}$ and Danish (2).

The information on the nationality of the different contributors to IJL is taken from the contributions themselves (i.e. the information on the country of residence), as these are always given (in reviews at the end, and in articles at the beginning). This is not the case with LexicoNordica. Only in recent years has it become common practice to give information about the contributors at the end of each contribution, therefore languages and not countries have been chosen above for contributors to LexicoNordica. However, the languages used in LexicoNordica do not equal the nationality of the contributors: For instance, Finnish scholars always publish in Swedish (mostly in Finno-Swedish, i.e. Swedish as spoken and written in Finland), even though it is allowed to publish in Finnish, whereas Icelandic, Faroese and Greenlandic scholars usually publish in Danish (some Icelandic scholars also publish in Norwegian), because most scholars in Scandinavia understand Swedish, Norwegian Bokmål, and Danish, but only a few understand Finnish, Icelandic, Faroese and Greenlandic (i.e. Inuit). In addition: All Finno-Swedish contributions are regarded as Swedish contributions in the above discussion.

Even though it is debatable what a classic is, the citation figures shown above combined with the fact that Svensén's handbook seems to be a steady seller, indeed points in the direction that Svensén's handbook is about to become a classic; even if not in the world generally, certainly in Scandinavia specifically. 


\section{Endnotes}

1. The number of scholars is actually 14 , because two of the relevant contributions are written by two scholars each; however, the number of citations is 12 equalling the 12 contributions.

2. Mixed origin: One of the IJL contributions is written by three scholars (the one from the USA, the other from Spain, and the third from The Netherlands); two of the IJL contributions are written by one scholar working in Europe (Belgium) as well as in Africa (South Africa); the Australian contribution is written by two scholars. Two of the contributions actually appeared in the EURALEX Newsletter included in IJL, and not in IJL itself: One of these contributors is from the USA, the other is from Europe.

3. Four of the European contributions citing Landau's book are written by two different European scholars each (i.e. eight scholars in total).

4. One of the three Japanese contributions citing Landau's book is written by five Japanese scholars.

5. One of the two Canadian contributions citing Landau's book is written by two Canadian scholars.

6. The Jordanian contribution citing Landau's book is written by two Jordanian scholars.

7. The Australian contribution citing Landau's book is written by two Australian scholars.

8. These two contributions citing Landau's book are written by the same scholar working in Europe (Belgium) as well as in Africa (South Africa).

9. One of the Swedish contributions citing Svensén's book is written by two Swedish scholars.

10. Two of the Danish contributions citing Svensén's book are written by two Danish scholars each (i.e. four scholars in total); and one of these contributions cites two different versions (i.e. Svensén 1993 and 2004).

11. Three of the Norwegian contributions citing Svensén's book are written by two Norwegian scholars each (i.e. six scholars in total).

12. One of the Swedish contributions citing Landau's book is a translation (by someone else than the author) of a review article originally written in German, for the purpose of being published in LexicoNordica; whether the German version has been published as well, is not clear from the information given in a note at the end of the contribution; information is only given on the fact that it has been translated from a German original.

13. One of the Swedish contributions citing Zgusta's book is a translation of a review article originally written in German (see note 12 above).

\section{References}

Burkhanov, I. 1998. Lexicography: A Dictionary of Basic Terminology. Rzeszów: Wydawnictwo Wyższej Szkoły Pedagogicznej.

Considine, J. 2008. Dictionaries in Early Modern Europe: Lexicography and the Making of Heritage. Cambridge: Cambridge University Press.

Hartmann, R.R.K. and G. James. 2006. Dictionary of Lexicography. London/New York: Routledge. [First Edition 1998].

Hausmann, F.J., O. Reichmann, H.E. Wiegand and L. Zgusta (Eds.). 1989-1991. Wörterbücher. Ein internationales Handbuch zur Lexikographie/Dictionaries. An International Encyclopedia of Lexico- 
graphy/Dictionnaires. Encyclopédie internationale de lexicographie. Volume 1-3. Berlin/New York: Walter de Gruyter.

Kabdebo, T. and N. Armstrong. 1997. Dictionary of Dictionaries and Eminent Encyclopedias: Comprising Dictionaries, Encyclopedias, and other Selected Wordbooks in English. Assisted by Etaín Ó Síocháin. Second Edition. London: Bowker-Saur. [First Edition 1992].

Landau, S.I. 1984. Dictionaries: The Art and Craft of Lexicography. First Edition. New York: Charles Scribner's Sons.

Landau, S.I. 1989. Dictionaries: The Art and Craft of Lexicography. Reprint of the First Edition. Cambridge/New York: Cambridge University Press.

Landau, S.I. 2001. Dictionaries: The Art and Craft of Lexicography. Second Edition. Cambridge/New York: Cambridge University Press.

Martínez de Sousa, J. 1995. Diccionario de lexicografía práctica. Barcelona: Biblograf.

McCreary, D.R. 1997. [Review of] Bo Svensén: Practical Lexicography. Principles and Methods of Dictionary-Making. Translated from the Swedish by John Sykes and Kerstin Schofield. Oxford/New York: Oxford University Press 1993. International Journal of Lexicography 10(4): 346348.

Pálfi, L.-L. 2009a. LexicoNordica. EURALEX Newsletter, Summer 2009. International Journal of Lexicography 22(2): 234-235.

Pálfi, L.-L. 2009b. [Review of] John Considine: Dictionaries in Early Modern Europe: Lexicography and the Making of Heritage. Cambridge: Cambridge University Press 2008. Lexikos 19: 509-515.

Pálfi, L.-L. 2009c. [Review of] A.P. Cowie (Ed.): The Oxford History of English Lexicography. Volume I: General-purpose Dictionaries. Volume II: Specialized Dictionaries. Oxford: Oxford University Press 2009. Lexikos 19: 516-523.

Pálfi, L.-L. 2010a. Leksikon over ordbøger og leksika. Assisted by J.F. Lindholm. Copenhagen: Frydenlund.

Pálfi, L.-L. 2010b. Det digitale hysteri — eller kunsten at synge i kor. BogMarkedet 9: 25.

Svensén, B. 1987. Handbok i lexikografi. Principer och metoder $i$ ordboksarbetet. Stockholm: Esselte Studium \& Tekniska Nomenklaturcentralen.

Svensén, B. 1993. Practical Lexicography. Principles and Methods of Dictionary-Making. Translated from the Swedish by John Sykes and Kerstin Schofield. Oxford/New York: Oxford University Press.

Svensén, B. 2004. Handbok i lexikografi. Ordböcker och ordboksarbete i teori och praktik. Second, Revised and Extended Edition. Stockholm: Norstedts Akademiska Förlag.

Svensén, B. 2009. A Handbook of Lexicography. The Theory and Practice of Dictionary-Making. Cambridge: Cambridge University Press.

Tarp, S. 2005. Anmeldelse af Bo Svensén: Handbok i lexikografi. Ordböcker och ordboksarbete i teori och praktik. Andra, omarbetade och utökade upplagan. Stockholm: Norstedts Akademiska Förlag 2004. LEDA-Nyt 39: 5-8.

Tarp, S. 2008. Lexicography in the Borderland between Knowledge and Non-Knowledge. General Lexicographical Theory with Particular Focus on Learner's Lexicography. Lexicographica. Series Maior 134. Tübingen: Max Niemeyer Verlag.

Trap-Jensen, L. 2010. [Review of] Bo Svensén: A Handbook of Lexicography. The Theory and Practice of Dictionary-Making. Cambridge: Cambridge University Press 2009. International Journal of Lexicography 23(2): 223-227. 
Varantola, K. 2006. [Review of] Bo Svensén: Handbok i lexikografi. Ordböcker och ordboksarbete i teori och praktik. Second, Revised and Extended Edition. Stockholm: Norstedts Akademiska Förlag 2004. International Journal of Lexicography 19(1): 107-110.

Vikør, L.S. 2005. Ei metaleksikografisk perle. Bo Svensén: Handbok i lexikografi. Ordböcker och ordboksarbete i teori och praktik. Andra, omarbetade och utökade upplagan. Stockholm: Norstedts Akademiska Förlag 2004. LexicoNordica 12: 331-346.

Zgusta, L. 1971. Manual of Lexicography. The Hague: Mouton.

Zgusta, L. 1992/93. [Review of] Bo Svensén: Handbok i lexikografi. Principer och metoder i orboksarbetet. Stockholm: Esselte Studium \& Tekniska Nomenklaturcentralen 1987. Dictionaries 14: 176178. 